\title{
Dermatomyositis as a paraneoplastic syndrome of malignant melanoma or incidental coexistence?
}

\author{
Dermatomyositis - zespół paraneoplastyczny czerniaka złośliwego \\ czy przypadkowe współistnienie?
}

\author{
Magdalena Krajewska', Hanna Bartosik', Wojciech Krajewski², Agnieszka Hałoń ${ }^{3}$, Marian Klinger \\ 'Department of Nephrology, Wroclaw Medical University, Wroclaw, Poland \\ 2Department of Urology, Wroclaw Medical University, Wroclaw, Poland \\ ${ }^{3}$ Department of Pathomorphology, Wroclaw Medical University, Wroclaw, Poland
}

Przegl Dermatol 2016, 103, 285-288

DOI: 10.51 14/dr.2016.61776

\section{KEY WORDS:}

dermatomyositis, paraneoplastic syndrome, malignant melanoma.

\section{SŁOWA KLUCZOWE:}

zapalenie skórno-mięśniowe, zespół paranowotworowy, czerniak.
ADDRESS FOR CORRESPONDENCE:

Wojciech Krajewski

Department of Urology

Wroclaw Medical University

213 Borowska St

50-556 Wroclaw, Poland

phone: +48717331010

e-mail: wk@softstar.pl

\begin{abstract}
Introduction. Dermatomyositis is a rare systemic disease of connective tissue characterized by inflammation of the muscles and the skin. Malignant melanoma is a cancer that begins in melanocytes in the skin, mucosa of the rectum, intestine, oral cavity, external genitalia or in the eyeball.
\end{abstract}

Objective. Presentation of a patient with dermatomyositis as a possible paraneoplastic syndrome of malignant melanoma.

Case report. We present a case of a 56-year-old woman who was referred to us due to erythematous skin lesions on the limbs, face, neck and upper chest. The patient also complained of progressive muscle pain and weakness of the shoulder and pelvic girdle as well as of dysphagia. The patient had a small ulcerative lesion on the right foot that was removed. Histopathological evaluation revealed malignant melanoma cells, which were also present in the sentinel lymph node.

Conclusions. Screening in dermatomyositis patients should also be focused on melanoma, especially in cases with negative antibodies.

\section{STRESZCZENIE}

Wprowadzenie. Zapalenie skórno-mięśniowe jest rzadką chorobą układową tkanki łącznej, charakteryzującą się zapaleniem mięśni i skóry. Czerniak złośliwy jest nowotworem powstającym z melanocytów zlokalizowanych w skórze, błonie śluzowej jelita, odbytnicy, jamy ustnej, zewnętrznych narządach płciowych lub gałce ocznej.

Cel pracy. Przedstawienie przypadku zapalenia skórno-mięśniowego współistniejącego z czerniakiem, ponieważ zapalenie skórno-mięśniowe jako zespół paraneoplastyczny towarzyszący czerniakowi złośliwemu jest sporadycznie zgłaszane.

Opis przypadku. Przedstawiamy przypadek 56-letniej kobiety, która zgłosiła się z powodu rumieniowatych zmian skórnych na kończynach, twarzy, szyi i dekolcie. Pacjentka skarżyła się także na postępujące osłabienie, ból mięśni obręczy barkowej i biodrowej oraz na dysfagię. Badanie fizykalne ujawniło, że pacjentka miała niewielką, niegojącą się, wrzodziejącą zmianę na prawej stopie, która została następnie usunię- 
ta. Ocena histopatologiczna wykazała obecność komórek czerniaka, które stwierdzono również w wartowniczym węźle chłonnym.

Wnioski. Diagnostyka u pacjentów z objawami zapalenia skórno-mięśniowego powinna uwzględnić również czerniaka, zwłaszcza u pacjentów z negatywnymi mianami przeciwciał.

\section{INTRODUCTION}

Dermatomyositis (DM) is a rare systemic disease of connective tissue characterized by inflammation of the muscles and the skin. The disease can also affect the heart, lungs and blood vessels. The pathogenesis is unknown, but it is believed that DM is caused by autoimmunological phenomena in genetically predisposed people who are exposed to external factors (e.g. infection). Symptoms of DM include general symptoms (weakness, fever), muscle manifestation (symmetric weakening of shoulder and pelvic girdle and head and neck muscles), cutaneous lesions (heliotrope rash, erythematous lesions on the back, shoulders and upper chest and Gottron papules), heart damage, lung changes (interstitial lung disease) and intestinal motility disorders. In DM treatment a combination of glucocorticosteroids and immunosuppressive drugs is used [1].

Malignant melanoma (MM) is a malignant tumor that begins in melanocytes localized in the skin, mucosa of rectum, intestine, oral cavity, external genitalia or in the eyeball. It is more common in lightskinned, blue-eyed females and frequently develops from dysplastic skin lesions. Malignant melanoma has the form of heterogeneous nodules of various color (from burgundy to black, but colorless lesions are also possible) with possible ulceration. Malignant melanoma metastasizes by blood and lymph vessels into lymph nodes, liver, lungs, brain and bones. Malignant melanoma is generally treated by surgery with lymphadenectomy. Chemotherapy and radiotherapy have limited importance [2]. In the available literature only a few cases of coexisting dermatomyositis and malignant melanoma can be found.

\section{OBJECTIVE}

Presentation of a case of a 56-year-old woman with DM and possibly associated MM.

\section{CASE REPORT}

In August 2013, a 56-year-old hypertensive woman was referred to a rheumatology department due to erythematous skin lesions of the limbs, face, neck and upper chest. The patient complained of progressive muscle pain and weakness of the shoulder and pelvic girdle as well as dysphagia.

A small, painless ulcer on the outer edge of the right foot in the area of the fifth metatarsal bone was also noted. It was approximately $1 \mathrm{~cm}$ wide with smooth edges, without discoloration, covered with
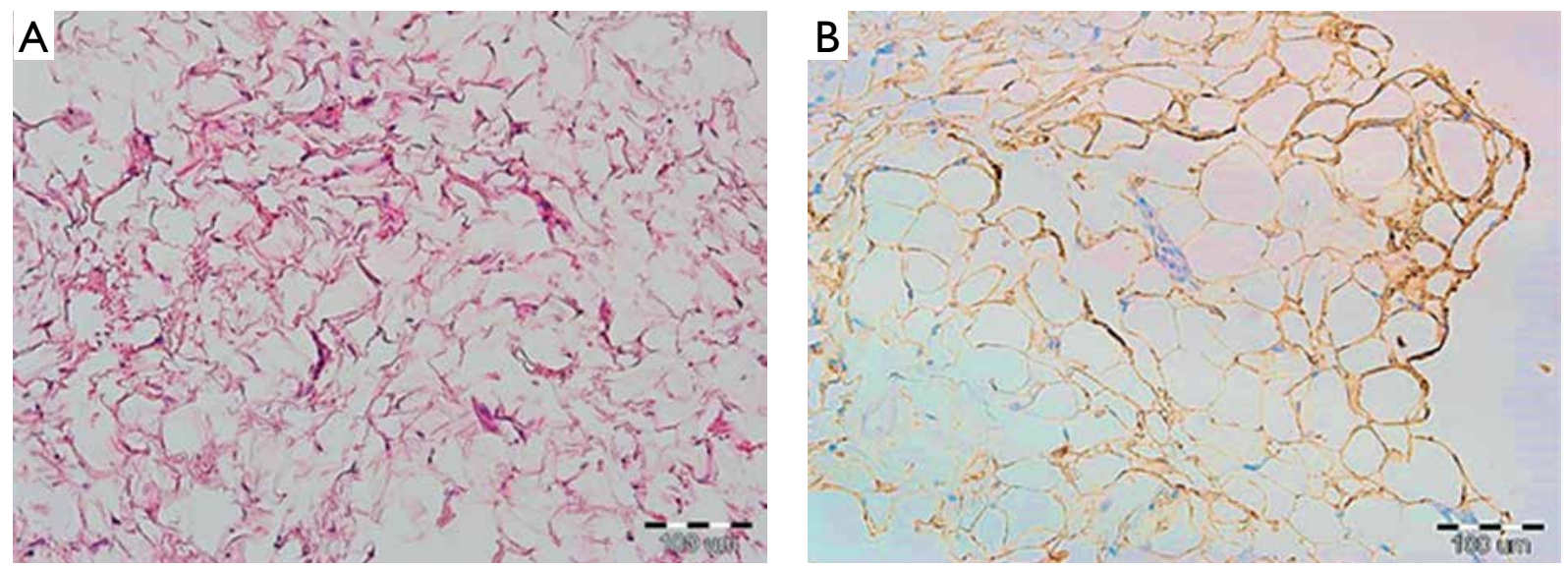

Figure I. Abdominal subcutaneous fatty tissue biopsy specimen. $\mathbf{A}-\mathrm{H}+\mathrm{E}$ staining with minimal eosinophilic extracellular material accumulation. B - Immunohistochemical staining for amyloid A antibody

Rycina I. Bioptat podskórnej tkanki tłuszczowej powłok brzusznych. A - Barwienie H + E z niewielkim odkładaniem się zewnątrzkomórkowo materiału kwasochłonnego. B - Barwienie immunohistochemiczne na obecność amyloidu A 
granulomatous tissue on the sides and bottom. The surrounding area was unchanged.

Laboratory studies revealed increased levels of C-reactive protein (CRP, $17.16 \mathrm{mg} / \mathrm{l})$, creatinine kinaze (CK, $12509 \mathrm{U} / \mathrm{l})$, lactate dehydrogenase $(\mathrm{LDH}, 531 \mathrm{U} / 1)$, glutamic oxaloacetic transaminase (GOT, $81 \mathrm{U} / \mathrm{l})$ and glutamic pyruvic transaminase
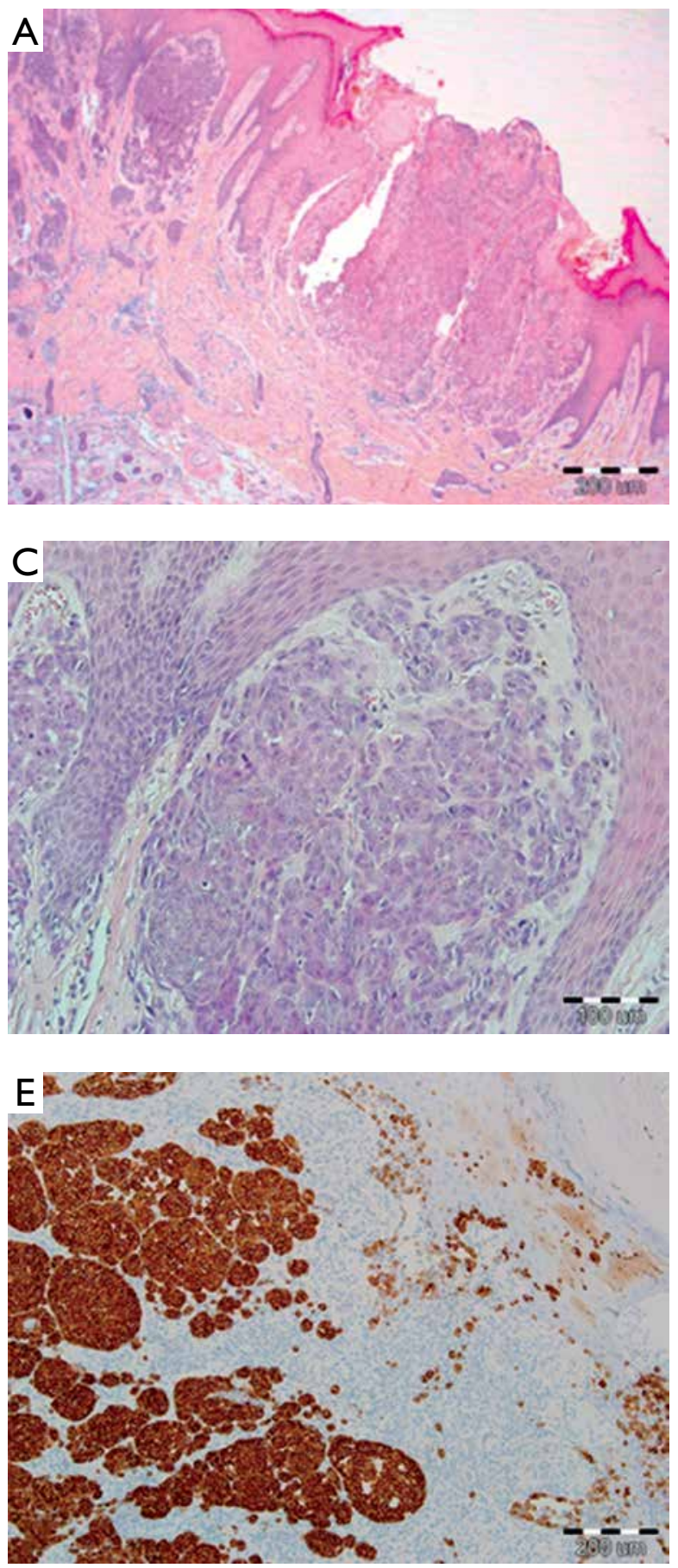

(GPT, $70 \mathrm{U} / 1)$. Skin and muscle biopsy and electromyography examination confirmed the diagnosis of DM. There was no evidence of immune disease activity (nRNP/Sm, Sm, SS-A, Ro-52, SS-B, Scl-70, PM-Scl, Jo-1, CENP B, PCNA, dsDNA, nucleosomes, histones, ribosomal P-proteins, AMA M2 antibodies and rheumatoid factor were negative; total hemolyt-

Figure 2. Advanced malignant melanoma with massive ulceration (A), epidermis invasion (B), deep dermal invasion (C), nest of highly pigmented melanoma cells $(D)$, immunohistochemical reactivity of melan $A(E)$, immunohistochemical reactivity of HMB45 (F)

Rycina 2. Zaawansowany czerniak złoślimy z masywnym owrzodzeniem (A), inwazja naskórka (B), głębokie naciekanie skóry właściwej (C), gniazda silnie pigmentowanych komórek czerniakowych $(D)$, dodatnia reakcja immunohistochemiczna na obecność melanu $A(E)$, dodatnia reakcja immunohistochemiczna na obecność HMB45 (F) 
ic complement activity C3 and C4 serum levels were in the normal range; cANCA and pANCA antibodies were negative). Oral corticosteroids (prednisone: 40$60 \mathrm{mg}$ /day), as well as pulses of methylprednisolone (total dose of $3 \mathrm{~g}$ ) were administered with no improvement. An attempt to apply methotrexate was unsuccessful owing to severe anemization and intolerance symptoms. Extensive neoplastic screening (gastroscopy, colonoscopy with excision of a polyp, ultrasound of abdomen, X-ray of thorax, gynecological, ophthalmological and laryngological examination, tumor markers) was conducted, but it did not reveal any abnormalities.

In November 2013, due to numerous losses of consciousness evoked by bradyarrhythmia episodes, heart damage associated with DM was diagnosed and a cardiac pacemaker was implanted. Despite administered corticosteroid treatment, pain and skin lesions persisted (CK: $90 \mathrm{U} / \mathrm{l})$. The therapy was continued (methylprednisolone: $48 \mathrm{mg} /$ day) and cyclosporine A (CsA) (150 mg/day) was introduced. In March 2014 the dosage of methylprednisolone was gradually reduced to the target of $32 \mathrm{mg} /$ day and CsA was maintained at the previous dose of $150 \mathrm{mg} /$ day.

During the next follow-up visit in July 2014 proteinuria $(0.9 \mathrm{~g} /$ day $)$ with reduction in total serum protein $(5.8 \mathrm{~g} / \mathrm{dl})$ was found and a biopsy of fatty tissue demonstrated amyloidosis (Fig. 1); therefore the patient was referred to the nephrology department. At admission erythematous skin lesions were intensified and muscle pain made the patient unable to walk. No lymphadenopathy or hepatosplenomegaly was noted. Immunological tests were still negative except for an antinuclear antibodies titer of 320 . Therefore it was decided to discontinue CsA, reduce the steroid dose and repeat neoplastic screening. Bone marrow biopsy was also conducted, but no pathological changes were found.

Due to the fact that the small ulcer located on the skin of the right foot had not healed for several months, surgical treatment was chosen. The $1.5 \mathrm{~cm}$ ulceration was surgically removed, and melanoma malignum pT3b, Clarke IV, Breslow thickness of $2.2 \mathrm{~mm}$ was found (Fig. 2). Biopsy of the sentinel lymph node revealed melanoma cells. Popliteal lymph nodes were free from MM.

The patient was transferred for further oncological treatment.

\section{DISCUSSION}

The coincidence of malignant neoplasms with DM is well known. More than 25\% of DM cases are associated with tumors, such as lung, prostate, breast, ovarian and stomach cancer. Nevertheless, the mech- anism by which malignant tumors influence the pathogenesis of DM is not certain [3].

Malignant melanoma is a common tumor, but the association of MM with DM is described in the available literature only 25 times [4,5]. Symptoms of DM in the course of MM appear before, simultaneously or after MM diagnosis [6].

Reports refer mainly to women with cutaneous and muscle involvement. The majority of the cases published to date show that the DM appeared at a late tumor stage. Eighty-nine percent of patients with MM were in stage III or stage IV, and only $11 \%$ were in stages I-II [4]. In our patient an advanced stage of MM was found too.

It is shown in the literature that dermatomyositis can indicate progression of MM with metastases to lymph nodes or distant organs [7].

It was also proven that if MM is in stage III, coexistence of DM does not worsen the prognosis, unlike in stage IV, when comorbidity of MM gives a poorer prognosis [7]. On the basis of available literature and the present case, it is not possible to ascertain whether the relationship between MM and DM has a causative character. However, this should focus screening and also increase attention on MM, which in less advanced stages can be difficult to detect, especially in cases with negative antibodies.

\section{Conflict of interest}

The authors declare no conflict of interest.

\section{References}

1. Femia A.N., Vleugels R.A., Callen J.P.: Cutaneous dermatomyositis: an updated review of treatment options and internal associations. Am J Clin Dermatol 2013, 14, 291-313.

2. Kauffmann R.M., Chen S.L: Workup and staging of malignant melanoma. Surg Clin North Am 2014, 94, 963-972.

3. Airio A., Pukkala E., Isomaki H.: Elevated cancer incidence in patients with dermatomyositis: a population based study. J Rheumatol 1995, 22, 1300-1303.

4. Fernandez-Crehuet P., Perez-Gil A., Herrera-Saval A., Cantalejo-Rodriguez C., Rios-Martin J.J., Camacho-Martinez F.M.: Dermatomyositis and malignant melanoma: a rare association that worsens prognosis? Intern Med J 2014, 44, 1041-1043.

5. Tu J., Von Nida J.: Metastatic malignant melanoma and dermatomyositis: a paraneoplastic phenomenon. Australas J Dermatol 2011, 52, e7-e10.

6. Liakou A.I., Trebing D., Zouboulis C.C.: Paraneoplastic dermatomyositis associated with metastatic melanoma. J Dtsch Dermatol Ges 2012, 10 63-64.

7. Schiller M., Bohm M., Hensen P., Riemann H., Luger T.A., Nashan D.: Dermatomyositis associated with malignant melanoma: a marker of poor prognosis? J Am Acad Dermatol 2006, 54, 221-226.

Submitted: 18 IV 2016

Accepted: 27 VI 2016 